\title{
The October 13, 2010 Landslides on the Azenge Mountain in Imande Ukusu, Nkomon Disrict, Benue State, Nigeria
}

\author{
Ako Thomas Agbor*, Abba Francis Mohammed, Onoduku usman Shehu, Nuhu Waziri Musa, \\ Alabi Adekola A., Mamodu Adegbe \\ Department of Geology, School of Natural and Applied Sciences, Federal University of Technology, Minna, Nigeria \\ *Correspondent author: akoagbor@futminna.edu.ng
}

Copyright (C) 2014 Horizon Research Publishing All rights reserved.

\begin{abstract}
A swarm of 14 landslides occurred spontaneously within the Azenge Mountain on November $13^{\text {th }}, 2010$ between the hours of 1 and 6 am after torrential rains. The landslides were studied using interviews, field observations and laboratory study of the soil samples collected from the major landslide site. Results of the study show that the event that was reported by many local media in Nigeria as volcanic eruption was a spontaneous massive slope movement along the mountainous terrain of Imande Ukusu, Mon village. About 1,123,918 $\mathrm{m}^{3}$ of rock and debris were moved along the sliding surface for more than $1.5 \mathrm{~km}$ to the toe of the mountain within a very few minutes. The size of the materials moved decreases from the top to the toe of the slope which range from $50^{\circ}$ to $5^{\circ}$ respectively. These materials range in size from block of rocks of various sizes, soil to mud. The largest boulders moved measured $71.2 \mathrm{~m}$ and $88.5 \mathrm{~m}$ respectively. The rock types in the area include gneisses, granites, basaltic rocks and dolerite dykes which have a general strike of $240^{\circ} \mathrm{NW}$ with a dip of $038^{\circ} \mathrm{NE}$ and are highly fractured. The fractures and dip are in the direction of the slope. Laboratory result of the soil samples reflect two types of grain sizes. Those with very high degree of susceptibility to sliding above the sliding surface which plot in the failure zone and those less susceptible from the sliding surface and plot outside the failure zone. Torrential rainfall towards the end of the year was the main triggering mechanism of the landslides. Other causes are attributed to geological, morphological and human factors. The landslides led to the death of 1 person, destruction of vegetation, soil structure and texture, farmlands and remodeling of the geomorphology of the area. It is recommended that human activities along the toe of the hills be reduced and settlements should be sited far away from the hills to avoid further loss of lives in future.
\end{abstract}

Keywords Landslide Scar, Imande Ukusu, Nkomom District, Sliding Surface, Boulders and Debris, Susceptible

\section{Introduction}

Landslides are geological phenomenon which occurs as a result of ground movement, rock falls, and failure of unstable slopes; sand and debris flow on slope and can cause a lot of damages with direct and indirect effect on human settlements and physical infrastructure [1]. According to [2] landslide describes a wide variety of processes that result in the downward and outward movement of slope forming materials including rocks, soil, artificial fills or a combination of them. Landslides are common in areas where slope stability has been compromised.

Several landslides have occurred in Nigeria but many of them are not recorded except when people are killed and/or a good number of properties are destroyed. Literature on landslides in Nigeria is limited to short reports from the Nigeria Geological Survey Agency (NGSA), Ministry of Environment, internet and eye-witness reports that simply make mention of the disaster and casualties [3]. No thorough investigation regarding the triggering mechanism and extent and nature of the landslides is usually carried out. Description of the various possible causes of the landslides and nature of the rocks types and weathered materials affected are also not always reported. Most of the occurrences may not have been reported due to negligence and lack of appreciation of this natural phenomenon at both States and Federal levels. Landslides have occurred over the time in some parts of Nigeria destroying lives and properties such as in Ohsun, Benue, Enugu, Abia, Anambra, Ebonyi and Imo (figure 1).

According to [3], landslides occur in different parts of southern Nigeria due to wide spread impact of gully erosion resulting from annual rainfall and subsequent flooding. Their result showed that landslides occur mostly as earth movement, rock and occurred in the Ogbajala hills of Benue State on $3^{\text {rd }}$ September, 1987 after days of consecutive rainfall and subsequent flooding. Field measurement of the landslides showed that the slip originated on the upper one third of the hill at depth of $1.37 \mathrm{~m}$ and extended uniformly to about $50 \mathrm{~m}$ down slope before turning into a flow [4]. Similarly, in September, 1997, two separate rain-induced complex landslides occurred along the slope of the Akovolwo mountains near Jato-Aka in Kwande Local 
Government area of Benue State. The two movements developed on bedrock slopes covered by veneer of colluviums and/or residium not more than 1.5 to $2 \mathrm{~m}$ deep.

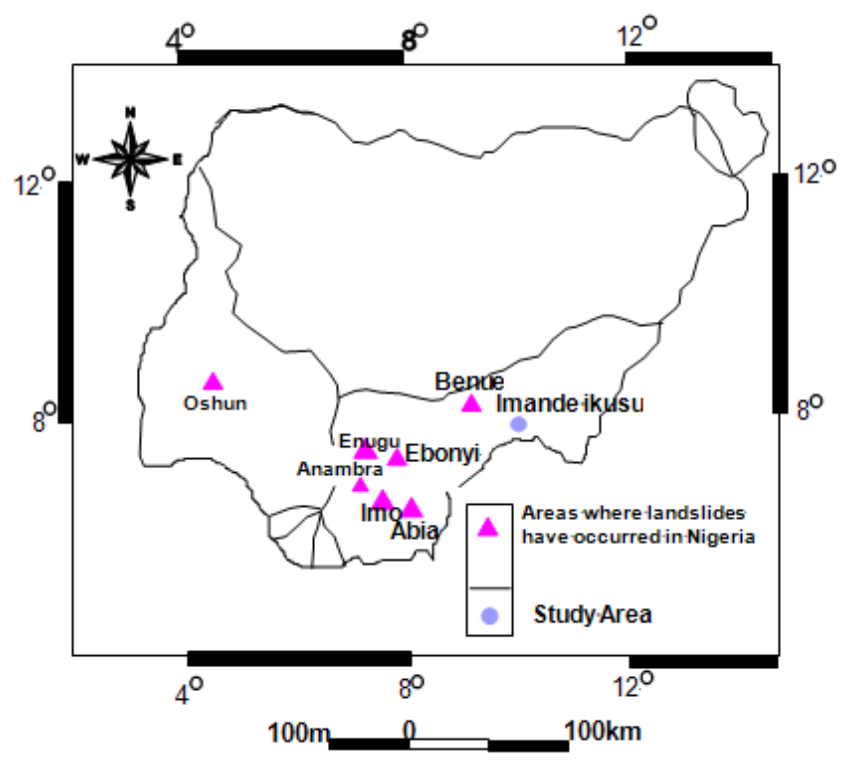

Figure 1. Map of Nigeria showing areas where landslides have occurred(adopted from [ 3 ]).

On Thursday, $9^{\text {th }}$ November, 2010, The Sun Newspaper reported the occurrence of volcanic eruption in Benue State supporting its report with a photo of smoke, fire and ash that normally accompany volcanic eruptions. The Guardian Newspaper also reported this on Tuesday, November $9^{\text {th }}$, 2010 edition of the occurrence of a volcanic eruption in Benue State. It was as a result of these reports that led to this study in Imande Ukusu, Mon village in Nkomon district, Kwande Local Government Area of Benue State where it was discovered that what was widely reported by the media was not really a volcanic eruption but a series of landslides.

This work is therefore aim at studying the degree and extent of the landslides that occurred in the study area on the $13^{\text {th }}$ of October, 2010. Also, identification of the geology of the affected area, determination of the triggering mechanism of the landslides, effects on people and the environment and mitigation measure are discussed. This will assist to evaluate the disaster and risks associated with landslides and eventually provide guidance for the management of such events in Nigeria and other parts of the world.

\section{Geology and Geography of the Study Area}

The geology of Benue State consists of both Precambrian Basement Complex and Tertiary sedimentary rocks. However, much part of the state falls within Benue valley/trough formed during the Tertiary and possible the inter-glacial periods of the Quaternary glaciations. During this period, the Benue and Niger valleys, otherwise known as the Niger/Benue trough, were transgressed by the water of the Atlantic Ocean. Consequently, marine sediments form the dominant surface geology of much of the state. The sediments within the trough have undergone varying grades of metamorphism and are underlain at variable depth by Basement Complex rocks [5]. The sediments are dominantly sandstones with some shales, siltstones and limestone. Basement Complex rocks occur at higher topography further away, especially in Kwande along the Cameroon-Nigeria boarder. The area is part of the Cameroon Hot Line (CHL) also known as the Cameroon Volcanic Line (CVL). This is an active $\mathrm{N} 30^{\circ} \mathrm{E}$ tectono-magmatic alignment which extends from Pagalu Island to Lake Chad (Figure 2) [6, 7]. More recently, the CHL has been considered as a hot line resulting from lithospheric cracks $\left(\mathrm{N} 30^{\circ} \mathrm{E}\right)$ tapping a sublithosperic mantle [6]. These Basement Complex rocks comprise of igneous and metamorphic rocks including porphyritic granites, migmatites, diorites, pegmatite and gneisses. Both the Basement complex and Tertiary sedimentary rocks have been deeply weathered resulting in the formation of regolith and sapprolite tenths to hundredths of metres deep.

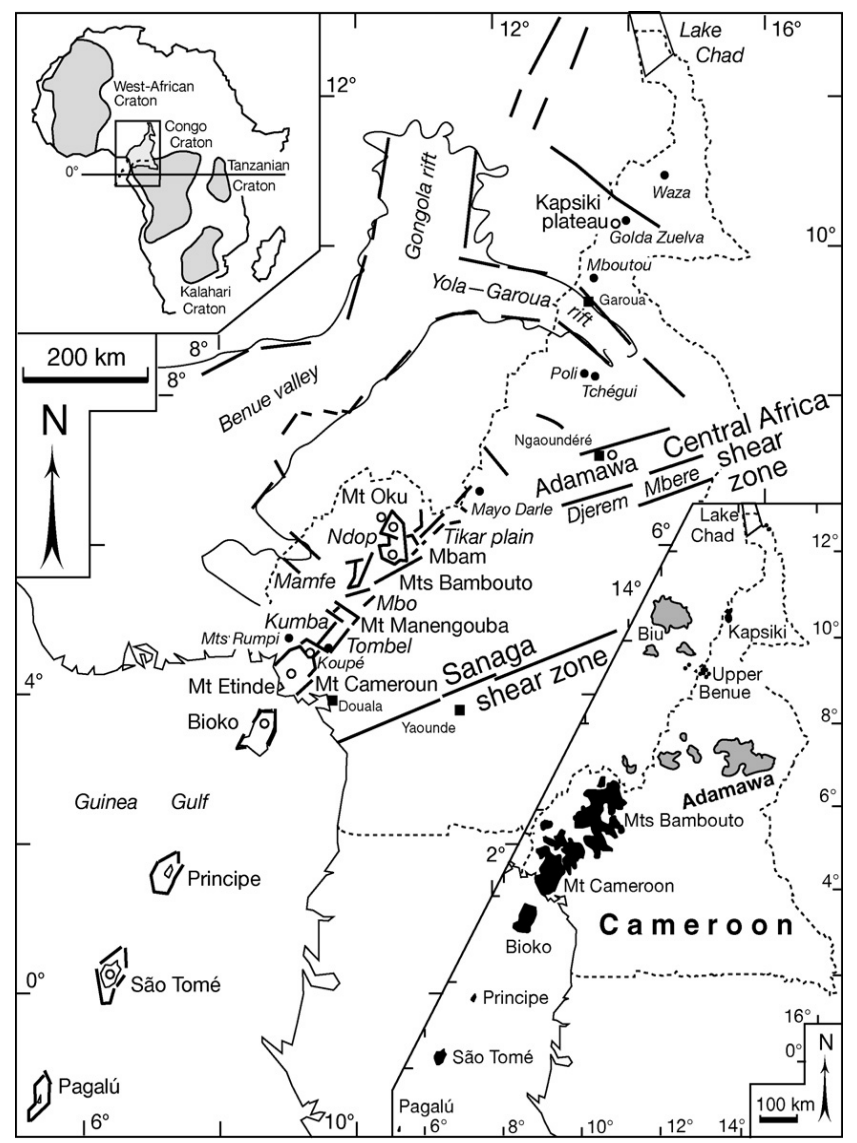

Figure 2. The Cameroon Hot Line ( $\mathrm{CHL})$ is a $\mathrm{N} 30^{\mathbf{0}}$ E-trending alignment that extends from Pagalu Island in the Gulf of Guinea to Lake Chad: it consists of oceanic and continental volcanoes and of anorogenic plutonic complexes ( black circles, small italics). From a structural point of view, the continental sector is a succession of horsts and grabens( graben names in large italics). Lower insert: Cainozoic volcanic rocks of the Cameroon Line (black) and of the other areas in the Adamawa and Biu Plateaux in Nigeria (grey) $[6,7]$. 
The study area falls within the Eastern and North-Eastern highlands [8]. These highlands consist of masses of basement complex rocks and plateaux of basaltic rocks within the range of 1800 to 2400 meters high. Imande Ikusu lies within the Cameroon-Nigeria boarder and is characterized by hilly terrain with appreciable local relief where the terrain is characterized by steep slopes and generally rugged topography. River Benue is the main river draining in the area into which smaller rivers like Nkomon, Amile, Aya and Katsina-Ala discharge.

The climate in the area is a tropical sub-humid type characterized by two distinct seasons; the wet and dry seasons. The wet or rainy season lasts for seven months from April while the dry season starts in November and ends in March. The annual rainfall total ranges from $1,200 \mathrm{~mm}$ to $1500 \mathrm{~mm}$.Temperatures in the area are generally very high during the day, especially in March and April. The state capital Makurdi, for examples, records average maximum and minimum daily temperatures of $35^{\circ} \mathrm{C}$ and $21^{\circ} \mathrm{C}$ in the wet season and $37^{\circ} \mathrm{C}$ and $16^{\circ} \mathrm{C}$ in the dry season. These relatively high humidity and high temperatures produce debilitating weather conditions. The study area lies in the Southern Guinea Savannah characterized by grasses and scattered trees which are mainly those of economic value such as locust beans, shear butter, mango and oil palm. However, dense forest occurs around Kwande, Vandeikya and Okpokwu. The forests are typically made up of rain forest trees such as Mahogany, Obeche, Iroko and Afara which are exploited fortimber and firewood [9].

\section{Materials and Methods}

\subsection{Field Work}

Fieldwork was carried out shortly after the event occurred. During the period, information on the landslides was gathered from eye witnesses and the representative of the village head. Information obtained from them includes the number of landslides that occurred along the slopes, the numbers of lives lost, number of farmlands and buildings destroyed. Apart from the eyewitness accounts, archival data on rainfall in $\mathrm{mm}$ for the year in question provided another important source of data for this research.

Mapping of the area was carried out to determine the geological and environmental factors that must have caused the landslides and attention was paid on the rock types, fractures and degree of slope and human activities along the slope toe of the hill and types and sizes of the materials moved. The length, width and depth of the landslide scar were also determined so as to calculate the volume of materials moved. The nature and amount of destruction to lives and property were recorded and finally collection of soil samples within the major landslide site for grain size analysis in the laboratory. The soil samples were collected from above, below and away from the landslide surface. Similarly, measurement of landslides scar was only taken from the major landslide site out of the 14 sites that occurred in the area that night. This is because it was at this site that great movement of materials occurred followed by severe destruction, while others were just small quantities of soils rolled along fractured zones without any measurable destruction to the environment.

\subsection{Laboratory Analysis}

The grain size analysis was performed in the Civil Engineering laboratory of Federal University of Technology, Minna, Nigeria. Grain size analysis was carried out on fourteen soil samples collected from the field. About $30 \mathrm{~g}$ of each sample was air-dried and ground to very fine particles using a ceramic crucible and pestle. Sieves with the following aperture sizes were used for the grain size analysis: $2.0 \mathrm{~mm}, 1.18 \mathrm{~mm}, 850 \mu \mathrm{m}, 600 \mu, 425 \mu, 300 \mu, 150 \mu$ and $75 \mu$. The stack of sieves was placed on a mechanical sieve shaker (state model and manufacturer here), and was vibrated for about ten minutes. The weight of the samples retained in each sieve was subsequently measured in order to ascertain the mass passed, percentage retained and cumulative percentage retained. The result of the grain size analysis was plotted on a grain sizes triangle after [10] and [11] to establish the range of grain sizes that are susceptible to sliding.

\section{Result}

\subsection{Eye Witness Accounts}

According to Hange Iordye, the tour guide and the representative of the village head of Imande Ukusu Mon, in Nkomon district, the landslides occurred on the $13^{\text {th }}$ October, 2010 in the morning between the hours of $1 \mathrm{am}$ and $6 \mathrm{am}$ after a torrential rain that lasted from $4 \mathrm{pm}$ on the $12^{\text {th }}$ of October, 2010 to $7 \mathrm{am}$ the next day. The sliding was accompanied by loud explosions and vibration that was heard in the surrounding villages within the district. A total of fourteen landslides occurred along the huge mountain range surrounding the area but only the one that caused most damage to the area was studied (Figure 3 ). According to him, only one person lost his life. He must have been killed by the remaining large boulders that were sliding towards the toe of the hill on his way to the farm around 5 am. No buildings were affected because human settlements were located away from the area where the landslide occurred.

\subsection{Field Observations}

The rock types encountered in the area include gneisses, granites, dolerite dykes and basaltic rocks. Field evidence indicated the existence of granites, gneisses and dolerites lying uncomformably on basaltic rocks. The rocks in the study area have a general strike of $340^{\circ} \mathrm{NW}$ with a dip of $038^{\circ} \mathrm{NE}$ and were highly fractured. The deep and penetrating 
fractures in the rocks must have brought about gradual weathering (Figure 4). This resulted in slow but steady decrease in the strength of the materials, thus increasing the likelihood of sliding along slopes with gradients of $50^{\circ}$ from the top to $5^{\circ}$ at the toe (Figure 5).

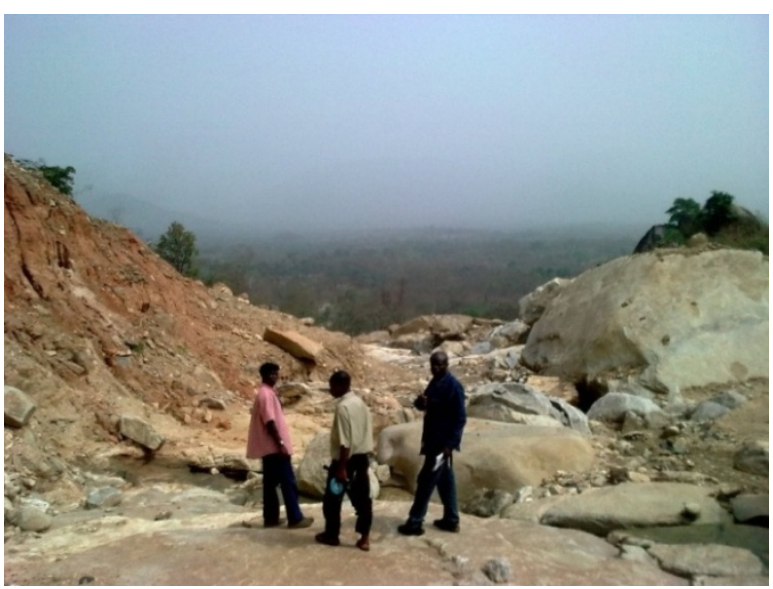

Figure 3. Photograph of major landslide out of the fourteen that occurred in the area

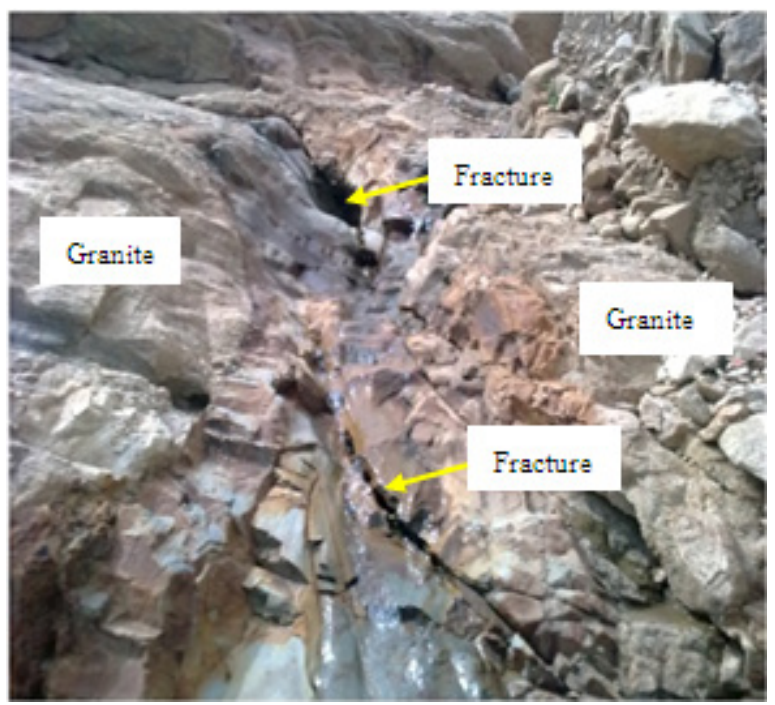

Figure 4. Photograph of fractures that permit water to percolate and cause weathering and weakness of the rock unit

The materials from the slide were made up of fine debris to large fragments of the granitic and gnessic basement complex which has been intruded by dark coloured rocks believed to be volcanic rocks. The materials were deposited along the sliding path and the grain size of the materials decreases from the top to the bottom of the hill. The materials that were moved to the foot of the hill were deposited in the bed and flood plain of the then existing river with a width of $38.5 \mathrm{~m}$ (Figure 6a). The deposition of the materials resulted in the diversion of the river course and development of a new river tangential to the old one (Figure 6b). Materials deposited were mainly small rock fragments, sand, mud and dead plant materials. The saturated soils following heavy rainfall acted as a lubricant for the materials to move rapidly and in mass down slope. The Azenge Mountain where the sliding took place has an elevation of between $950-2100 \mathrm{~m}$ above sea level and lies along the Nigeria-Cameroon boarder with slope angles ranging from $17^{\circ}$ at the top to $50^{\circ}$ at the foot or toe.

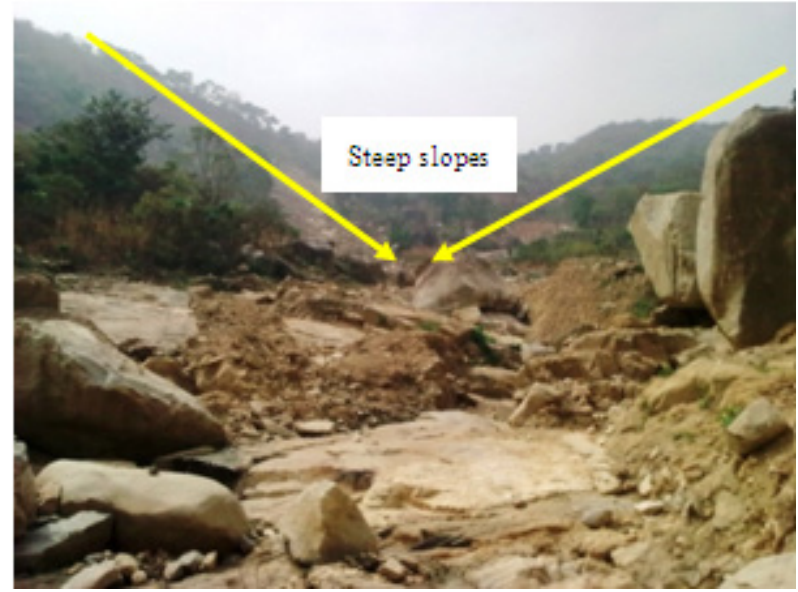

Figure 5. Photograph of steep slopes the facilitated the movement of material down slopes
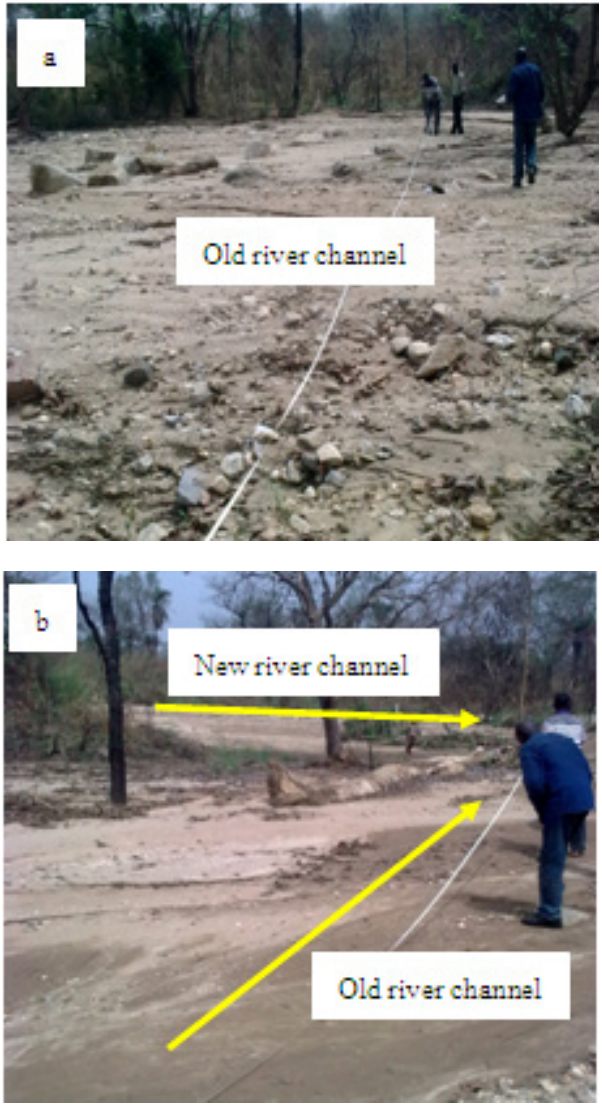

Figure 6. Photographs showing (a) materials deposited on the then river valley and (b) the development of a new river valley tangential to the old one

The landslide scar increased in width from the top $(20 \mathrm{~m})$ to the base $(75 \mathrm{~m})$ with an average depth of $58.73 \mathrm{~m}$ and a total length of $950 \mathrm{~m}$. The largest boulders moved measured $15 \mathrm{~m}$ long, $10.6 \mathrm{~m}$ wide and $52.5 \mathrm{~m}$ high (Figures $7 \mathrm{a}$ and $\mathrm{b}$ ). The sites of the 14 slides correspond to old fault planes 
which have acted as conduits for the flow of water.
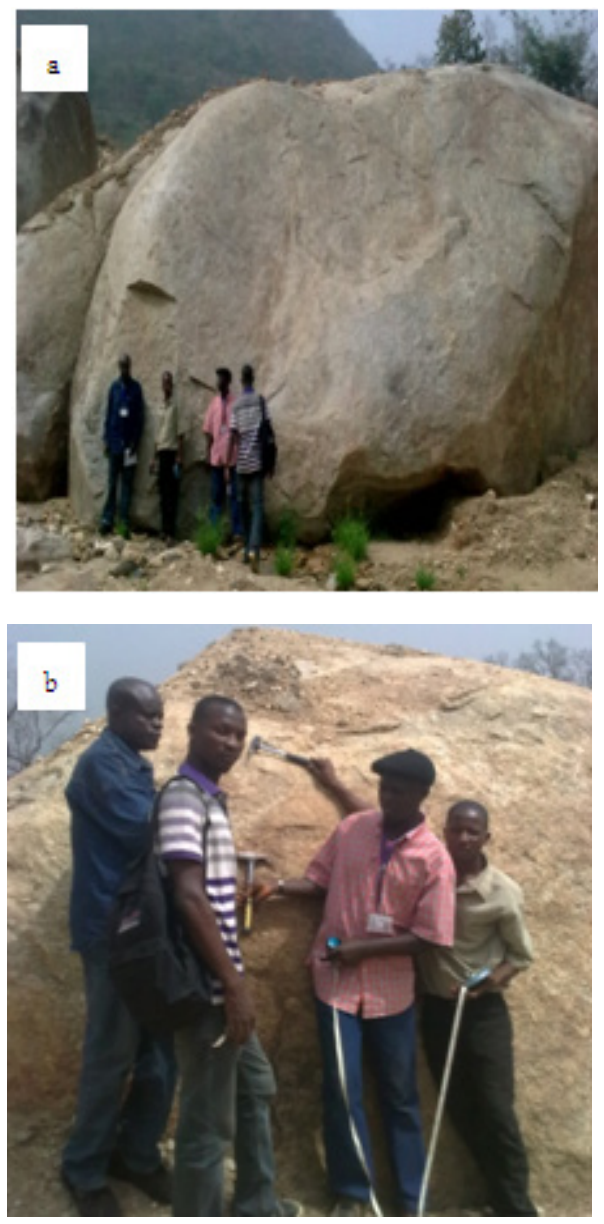

Figure 7. Photographs of boulders moved down slope (a) has a diameter of $71.2 \mathrm{~m}$ while (b) has a diameter of $88.5 \mathrm{~m}$. Size of materials moved decreases down the slope.

To calculate the volume of materials moved during the landslide, the average width and depth of the landslide scar was determined and the volume determined according to this formula [12]:

$$
\mathrm{V}=1 / 6 \pi(\mathrm{D}+\mathrm{W}+\mathrm{L})
$$

Where $\mathrm{V}=$ volume of the materials generated from the landslide

$\pi$ is a constant, 3.142

$\mathrm{D}=$ average depth of the landslide scar

$\mathrm{W}=$ average width of the landslide scar

$\mathrm{L}=$ total length of the landslide scar

Therefore, the volume of materials moved or generated from the landslides,

$$
\begin{gathered}
=0.1667 * 3.142(58.73 * 38.46 * 950) \mathrm{m} \\
=1,123,918 \mathrm{~m}^{3}
\end{gathered}
$$

Human activities like farming and lumbering have been taking place within the area where the sliding occurred. The erosive action of the river and flood waters at the toe or foot of the hill was very visible as small and steep gullies appeared within the area where the landslides occur (Figures $8 \mathrm{a}$ and $\mathrm{b}$ ).

Field investigation equally showed that three rice farms, plantain and yam farms of about 200 square $\mathrm{km}$ and a large number of palm trees and other economic trees were destroyed (Figures 9a and $b$ ).
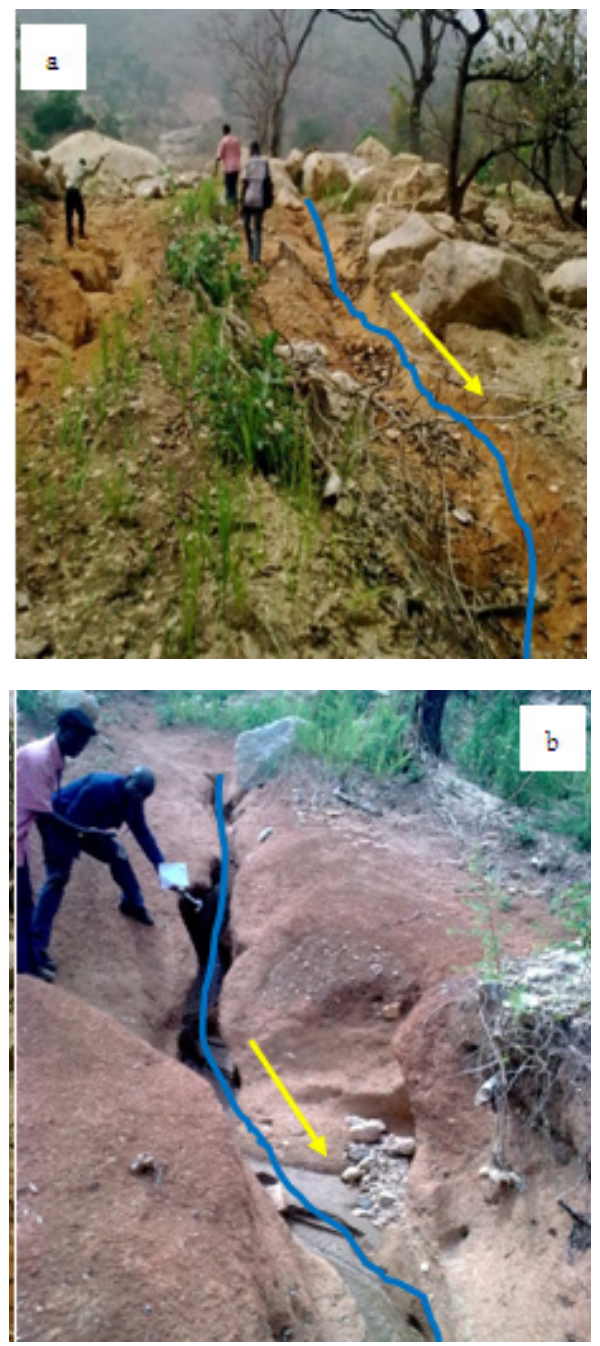

Figure 8. Photograph of gullies produced (a) at the top and (b) at the foot of the hill. Note the that depth and width of the gullies increases from the top to the foot of the hill

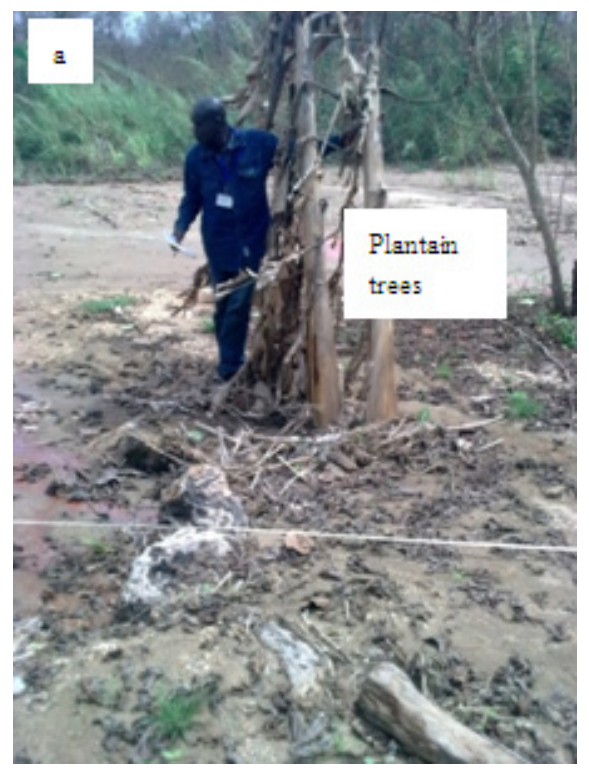




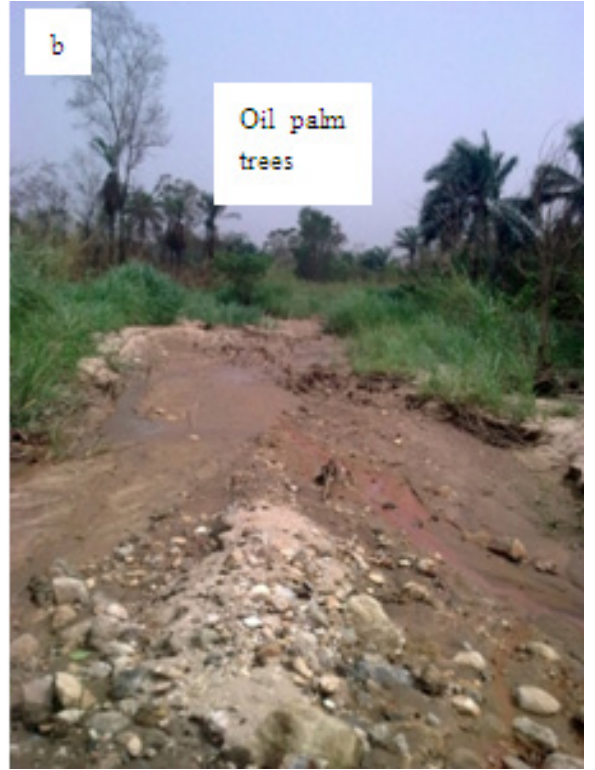

Figure 9. Photograph of (a) plantain and (b) oil palm trees destroyed by the landslide

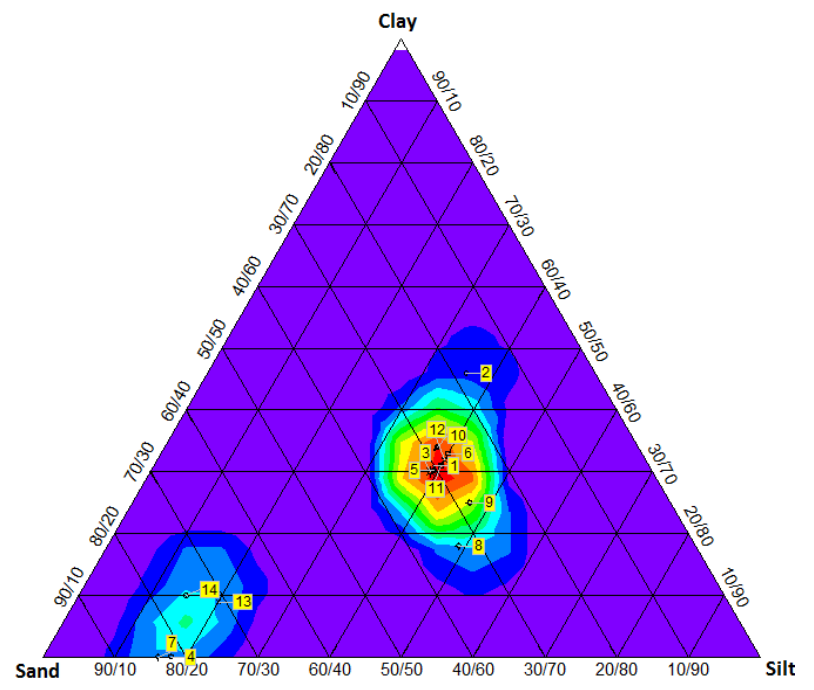

Figure 10. Plots of results of grain size analysis showing two groups of soils based on their susceptibility to sliding (modified from [12]).

According to [13], the annual rainfall for that year was between 1200 and $2000 \mathrm{~mm}$. The rainfall pattern for that year indicated two cycles of increasing rainfall that peaked in July and August and October which is usually considered as the last rains. This heavy rain is believed to have triggered the slides.

\subsection{Laboratory Results}

The results of sieve analysis of the fourteen soil samples collected from the landslides site is presented in table 1 and plotted figure 8 . These show that the soil display a wide range of grain sizes including clay, silt and sand fractions. However, most of the samples $(1,2,3,5,6,7,8,9,10,11$, and 12) are composed of mainly clay sized particles (Table 1 ). They are interpreted as soils of grain sizes that are mostly susceptible to sliding. These soils combined with water act as lubricant. A plot of these samples on the grain size triangle (Figure 10) reflects soil with very high degree of susceptibility to sliding above the sliding surface. However, four samples (i.e. 4, 7, 13, and 14) that were collected below the sliding and away from the sliding surfaces are mostly made up of sand and are less susceptible from sliding and plot outside the failure zone. These samples tend to be predominant of one grain size fraction that tends to cause instability within the unit (Figure 10).

Howard et al. [10, 11 and 12] carried out similar studies of soil from landslides and used the results to establish the range of soil grain sizes that are most susceptible to sliding and established that soils containing large amount of sand or gravel are less susceptible since their components have a stabilizing influence on the soil mass.

\section{Discussion}

The Imande Ukusu, Mon village landslides of $13^{\text {th }}$ October, 2013 must have been caused by several factors that range from geological, morphological to human factors. These causes maybe considered to be factors that made the slope vulnerable to failure. These factors predispose the slope to becoming unstable while the trigger is the single event that finally initiates the landslides. Generally this movement was induced probably because stresses in the slope were altered, by increasing shear stress or decreasing the effective normal stress or by reducing resistance to the movement due to decrease in the shear strength of the materials [14].

\subsection{Geological Causes}

Results from field investigation revealed that geological factors must have been responsible for the Imande Ukusu landslides. These geological factors range from weathering of rocks and soils, to changes in groundwater level and deformation of rocks in the area. The weathering of rock units and soil on the slope of the hills must have resulted to the weakening of the slope, causing the movement of materials downhill. The break down and decomposition of rocks by agents of denudation such as rain, temperature changes, plants and animals must have brought about the slow but steady decrease in material strength associated with the weathering of the rocks when the materials became so weak and failure occurred. Whitten [15] revealed that the introduction of water into a rock results in the chemical weathering of the rocks e.g. a sedimentary or igneous rock containing feldspar when weathered produce clay minerals which are platy-like and absorb water easily, thus, it swells weakening the bond between individual layers making it easy for the materials above to slide.

It is also suggested that rapid changes in the groundwater level along the slope of the hills triggered the landslides. This might have been as a result of rapid fall in the water level 
adjacent the slope leaving an artificial high water table that subjects the slope to higher than normal shear stress, leading to potential instability.

The landslides occurred during the second cycle of peak period of rain in the area. It can therefore be reasonable to conclude that rainfall played a significant role in the sliding. It caused an increase in the pore pressure in the soils underlying the slope. As the pore pressure of the slope increased along with a rise in the bulk density of the materials, the shear strength decreased, thus resulting in the slide. According to [3], landslides occur in different part of Nigeria due to widespread impact of gully erosion resulting from intense rainfall and subsequent flooding that results in slope failure. According to [16], such antecedent rainfall controls the soil moisture and is critical in limiting debris flow on slopes of $30^{\circ}$ to $40^{\circ}$. Furthermore, [17] found out that rainfall intensity and the original position of the ground water level, affect the stability of slopes. They further suggested that a slope could remain stable even under excessive rainfall, if the initial ground water level is low and that the factor of safety would only decrease if the duration of rainfall is increased.

The presence of too many fractures on both the rocks that were moved and those in the adjoining area suggests fractures in the rock provided passage for weathering fluids (Figure 4). Fractures in the rocks acts as common translational slip planes. The presence of some clay minerals along some fracture zones in the rocks supports the view that the landslides occurred as a result of absorption of water by these clay minerals $[14,18]$.

\subsection{Physical Factor}

The discharge of small springs along the slope and a stream along the foot of the hill must have produced failure as a result of the undercutting of the slopes, especially during the period (raining season) that the slides occurred. This undercutting serves both to increase the gradient of the slope, reduce stability and remove toe weighting which also reduces stability [19].

Table 1. Summary of results of grain size analysis of the soil samples from the study area

\begin{tabular}{|c|c|c|c|c|c|c|c|c|}
\hline Sample No. & \multicolumn{2}{|l|}{1} & \multicolumn{2}{|l|}{2} & \multicolumn{2}{|l|}{3} & \multicolumn{2}{|l|}{4} \\
\hline & $\mathrm{Wt}$ & $\%$ & wt & $\%$ & wt & $\%$ & wt & $\%$ \\
\hline Clay & 61.13 & 31 & 78.15 & 46 & 60.37 & 30 & 0.09 & 0.1 \\
\hline Silt & 76.35 & 39 & 62.15 & 36 & 77.95 & 39 & 18.21 & 18 \\
\hline Sand & 59.1 & 30 & 30.95 & 18 & 63.15 & 31 & 84.11 & 83 \\
\hline Total & 197 & & 171 & & 202 & & 102 & \\
\hline Sample No. & \multicolumn{2}{|l|}{5} & \multicolumn{2}{|l|}{6} & \multicolumn{2}{|l|}{7} & \multicolumn{2}{|l|}{8} \\
\hline & Wt & $\%$ & wt & $\%$ & wt & $\%$ & wt & $\%$ \\
\hline Clay & 60.3 & 30 & 33.4 & 33 & 0.06 & 0.1 & 35.2 & 18 \\
\hline Silt & 78.38 & 40 & 40.11 & 40 & 16.28 & 16 & 97.86 & 49 \\
\hline Sand & 59.8 & 30 & 27.1 & 27 & 83.59 & 84 & 65.95 & 33 \\
\hline Total & 199 & & 101 & & 100 & & 199 & \\
\hline Sample No. & \multicolumn{2}{|l|}{9} & \multicolumn{2}{|l|}{10} & \multicolumn{2}{|l|}{11} & \multicolumn{2}{|l|}{12} \\
\hline & $\mathrm{Wt}$ & $\%$ & wt & $\%$ & wt & $\%$ & wt & $\%$ \\
\hline Clay & 47.9 & 25 & 33.05 & 34 & 60.23 & 31 & 55.5 & 32 \\
\hline Silt & 91.59 & 47 & 36.8 & 38 & 77.17 & 40 & 69.1 & 40 \\
\hline Sand & 55.45 & 28 & 27.15 & 28 & 56.98 & 29 & 47.5 & 28 \\
\hline Total & 195 & & 97 & & 194 & & 172 & \\
\hline Sample No. & \multicolumn{2}{|l|}{13} & \multicolumn{2}{|l|}{14} & & & & \\
\hline & $\mathrm{Wt}$ & $\%$ & wt & $\%$ & & & & \\
\hline Clay & 9.13 & 9 & 10.15 & 10 & & & & \\
\hline Silt & 20.52 & 20 & 15.51 & 15 & & & & \\
\hline Sand & 72.01 & 71 & 75.65 & 75 & & & & \\
\hline Total & 102 & & 101 & & & & & \\
\hline
\end{tabular}




\subsection{Morphological Factor}

Slope and topography are seen as the main morphological factors that triggered the landslides of Azenge Hills in Nkomo District of Benue State. Field measurements indicated that the area is characterized by steep slopes ranging from $17^{\circ}$ at the top to $50^{\circ}$ at the base, deep valleys and generally rugged relief. This type of slope angle greatly affects the relative magnitude of the driving force on slopes. As the angle of potential slip plain increases, the driving force also increases, thus, landslides should be most frequent on steep slopes. A study of landslides that occurred during two raining seasons in California's San Francisco Bay area established that 75 to 80 percent of landslide activities is closely associated with urban areas on slopes greater than $15 \%$ or $8.5^{\circ}[20]$.

Vegetation is a very important factor in slope stability. Vegetation provides cover that cushions the impact of rain falling on slopes, facilitating infiltration of water into the slope while retarding grain- by- grain erosion on the surface. Also vegetation has root systems that tend to provide an apparent cohesion to the slope materials thus increasing resistance to landsliding. Therefore, the cutting down of trees for lumbering, firewood and farming along the slopes and toes of the hills exposed the slopes to all these factors, thus reducing the stability of the slopes and ultimately resulted in the fourteen landslides.

\section{Conclusion}

The geological event that occurred on the $13^{\text {th }}$ of October, 2010, in Imande Ukusu village was not an earthquake but a series of fourteen landslides. The landslides were triggered by continuous rainfall in the area which led to the percolation of much water into the rocks through fractures resulting to weathering of the rocks. The rock and soil materials saturated lost cohesion causing a mixture of rock boulders, fragments and soil to move down slope in large quantities. Apart from rainfall, other factors ranging from geological, morphological to human factors equally contributed to slope failure that led to the landslides.

The landslides did not have a high casualty figure on human as only one loss his life. However, farmlands and the natural vegetation in the area were destroyed. Also, the then normal river regime in the area was distorted resulting in the development of a new regime and the soil structure and texture in the area was also destroyed. It is therefore, recommended that human activities on the foot of the hill be reduced and settlements should be sited far away from the hills to avoid any lost of life.

\section{Acknowledgements}

We are grateful to the vice chairman of the then caretaker committee of Kwande Local Government, Benue State,
Nigeria, Engineer Benjamin Nyior and the chief security officer for providing transportation and security from Adikpo to Imande Ukusu. We also thank Professors Cho Emmanuel Suh and Ayonghe Samuel of the University of Buea, Cameroon, for their contributions and encouragement towards the realization of this work.

\section{REFERENCES}

[1] Renwick, W., Brumbaugh, R and Loeher, L. Landslide morphology and processes of Santa Cruz Island, California: journal of Geophysical Research, V.110, pp, 1982.

[2] Varnes, D. J. Slope movement types and processes. In Special Report 176: Landslides: Analysis and control (Eds: Schuster, R.L and Krizek, R.J), Transportation and Road research board, National Academy of Science, Washington D.C. $11-33,1978$.

[3] Igbokwe, J .I., Akinyede, J. O., Dang, B.Alaga,T.Ono, M. O., Nnodu, V. C. and Anike, L. O. Mapping and monitoring of the impact of Gully Erosion in Southeastern Nigeria with satellite Remote Sensing and Geographic Information System. International Archives of Photogrammetry, Remote Sensing and Spatial Information Sciences. Vol XXXVII, part B8, Beijing, pp 865-871, 2008.

[4] Okagbue, C. O. Stability analysis of a slip-debris flow in the Ogbajalala Hills of Benue State, Nigeria, Natural hazards, Volume 2, number 2, 143-153, 2003, DOI: 10.1007/BF00141244

[5] Obaje, N. G. Geology and Mineral Resources of Nigeria. Springer Dordrecht Heidelberg, London, New York, 2009, DOI: $10.1007 / 978-3-540-92685-6$

[6] B. Dervelle, I. Ngounouno and D. Demeiffe . "The Cameroon Hot Line" (CHL): A unique example of alkaline intraplate structure in both Oceanic and Continental lithosphere. C.R.Geoscience Elsevier, (339), 589-600, 2007.

[7] R. Montigny, I. Ngounouno, B. Deruelle. Ages K-Ar des roches magmatiques du fosse de Garoua (Cameroun) : leur place le cadre de la "ligne due Cameroun", C. R. Geoscience, 336, 1464-1471, 2004.

[8] Ileoje, N. P. A new geography of Nigeria. Longman, London, 1981

[9] http://www.onlinenigeria.com/links/benueadv.asp?blurb=21 2, 2/5/2011).S

[10] Howard, T. R. Baldwin H. J..E and Donly, H.E. Landslides in pacific California, caused by storm, in USSGS professional paper 1434, paper No. 9, pp 179-182, 1988.

[11] Talerico, J., Schuring, R. J. and Khera, R. P. Landslides in Glacial soils of New Jersey,. Proceedings of fifth international conference on case histories in Geotechnical Engineering, New York, 2004

[12] Ayonghe, S. N. and Ntasin, E. B. The geological control and triggering mechanisms of landslides of the 28th July, 2003 within the Bamboutos Caldera, Cameroon. Journal of the Cameroon Academy of Sciences, Vol. 7, No. 3, pp191-204, 2008. 
[13] Adamgbe, E. M. and Ujoh, F. Variations in climatic parameters and food crop yields: Implication on Food Security in Benue State, Nigeria. Confluence Journal of Environmental Studies, 7:56-67, 2012

[14] Plummer, C. C. Physical Geology (ninth edition). Mcgraw hill, 1221 Avenue of the Americas, New York. p111, 2003.

[15] Whitten, D.G.A. and J.R.V. Brooks (1972). Dictionary of Geology. Pp44 \& 162, 1972.

[16] Aghamelu, O. P., Nnabo, P. N. and Ezeh, H. N. Geotechnical and Environmental Problems related to Shales in the Abakaliki area, Southeastern Nigeria, African journal of Environmental Science and Technology, Vol. 5 (2), pp80-88, 2011.
[17] $\mathrm{Ng}$, C. W. W. and Shi, Q. Influence of rainfall intensity and duration on slope stability in unsaturated soil. Quarterly journal of Engineering Geology, 31, 105-113, 1998.

[18] Ayonghe, S.N., Ntasin, E. B., Samalang P, and Suh, C. E. The June 27, 2001 landslides on volcanic cones in Limbe, mount, Cameroon. West Africa Journal of Africa Earth Science, 39, pp 435-439, 2004.

[19] Nwajide, C. S., Okagbue C.O and Umeji, A. C. Slump debris flow in the Akovolvo Mountain of Benue State, Nigeria. Natural hazards, vol. 1 no. 2, 145-154, 2004 DOI: 10.1007/BF00126611

[20] Nilson, T. H., Taylor, F. A. and Dean, R. M. (1976). Natural conditions that control landsliding in the San Francisco Bay Region. U. S. Geological Survey, Bulletin 1424, 1976. 